\title{
Analisis Kinerja Pegawai pada Direktorat Sumber Daya Ditjen Dikti Kemendikbud
}

\author{
Santi Sayanti Agustina', Tatan Sukwika ${ }^{2, *}$ \\ 1,2Program Studi Magister Manajemen, Sekolah Pascasarjana, Universitas Sahid, Jakarta
}

\begin{abstract}
[Employee Performance Analysis in Directorate of Resources, Directorate General of Higher Education, Ministry of Education and Culture]. The performance indicators of the Directorate of Resources program in 2019 have not been maximized, only $77.60 \%$ has been achieved. For this reason, this study was conducted, which aims to determine the influence of internal employee factors, leadership, work team, work system and work environment on employee performance in the Directorate of Resources, so that we can get a picture and find out how much the relationship and influence on each variable to improve and improve the performance of employees in the Directorate of Resources. The analysis of this research uses a linkert scale and a rating scale, and hypothesis testing is carried out by analyzing Partial Least Squares Structural Equation Modeling (PLS-SEM) with the SmartPLS 3 application. The result of the research was obtained, employee internal factors, leadership, work team, work system and work environment. has an influence on employee performance. And employee internal factors that most dominantly affect employee performance in the Directorate of Resources. Based on this, efforts are needed for further research by exploring and developing other variables that can affect performance. Likewise, the object of research can be carried out on the same object or on different objects.
\end{abstract}

Keywords: Performance, Internal factors, Leadership, Work team, and Work environment

\begin{abstract}
ABSTRAK
Indikator kinerja program Direktorat Sumber Daya, pada Tahun 2019 belum maksimal, memiliki rataan kinerja $77.60 \%$. Untuk itu dilakukan penelitian ini, yang bertujuan untuk mengetahui Pengaruh Faktor internal pegawai, Kepemimpinan, Tim kerja, Sistem kerja dan Lingkungan Kerja terhadap Kinerja Pegawai di Direktorat Sumber Daya, sehingga didapatkan bagaimana gambaran dan mengetahui seberapa besar hubungan dan pengaruh pada masing-masing variabel, untuk memperbaiki dan meningkatkan kinerja pegawai di Direktorat Sumber Daya. Analisis penelitian ini menggunakan skala linkert dan rating scale, serta pengujian hipotesis dilakukan dengan analisis Partial Least Squares Structural Equation Modeling (PLS-SEM) dengan aplikasi SmartPLS 3. Hasil penelitian didapatkan, Faktor internal pegawai, Kepemimpinan, Tim kerja, Sistem kerja dan Lingkungan Kerja memiliki pengaruh terhadap Kinerja pegawai. Dan Faktor Internal Pegawai yang paling dominan mempengaruhi kinerja pegawai di Direktorat Sumber Daya. Berdasarkan hal tersebut, maka diperlukan upaya untuk penelitian selanjutnya dengan menggali dan mengembangkan variabel-variabel lain yang dapat berpengaruh terhadap kinerja. Begitu pula terhadap objek penelitiannya dapat dilakukan pada objek yang sama maupun pada objek yang berbeda.
\end{abstract}

Kata kunci: Kinerja, Faktor internal pegawai, Kepemimpinan, Tim kerja, Sistem kerja dan Lingkungan Kerja

*Alamat korespondensi

Alamat Afiliasi: Kampus Pascasarjana Usahid Jl. Jendral Sudirman No. 86, Jakarta 10220.

E-mail: tatan.swk@gmail.com
Histori Artikel:

Naskah masuk (received)

Naskah revisi (revised)

Naskah diterima (accepted)
: 21-04-2021

: 12-05-2021

: 03-06-2021 


\section{PENDAHULUAN}

Keberadaan sumber daya manusia (SDM) di Direktorat Sumber Daya, Direktorat Jenderal Pendidikan Tinggi memiliki peranan yang sangat penting. Dalam melaksanakan tugasnya, SDM diharapkan dapat memenuhi target yang ditetapkan oleh organisasi. Pengukuran ketercapaian sasaran kinerja Direktorat sumber daya, dapat dilihat dari realisasi atas Rencana strategis Direktorat Sumber daya, Direktorat Jenderal Pendidikan Tinggi, Kementerian Pendidikan dan Kebudayaan yang sebelumnya, nomenklatur pada tahun 2015 - 2019 bernama Direktorat Jenderal Sumber Daya Ilmu Pengetahuan, Teknologi, dan Pendidikan Tinggi, Kementerian Riset Teknologi, dan Pendidikan Tinggi (Ditjen SDID) yaitu meningkatnya relevansi, kualitas, dan kuantitas sumber daya ilmu pengetahuan, teknologi dan pendidikan tinggi.

Program peningkatan relevansi, kualitas, dan kuantitas sumber daya iptek dan dikti yang terdiri dari 5 (lima) indikator kinerja program yaitu: Persentase dosen berkualifikasi S3, Jumlah SDM yang meningkat karirnya, Jumlah SDM yang meningkat kompetensinya, Jumlah revitalisasi sarpras PTN, dan Persentase SDM Litbang Berkualifikasi S3 memiliki nilai rataan kinerja 77,60\%. Performa indikator kinerja masing-masing program selengkapnya disajikan pada tabel 1.

Tabel 1. Indikator Kinerja Sasaran Program Peningkatan Relevansi, Kualitas, dan Kuantitas Sumber Daya Iptek dan Dikti Tahun 2019

\begin{tabular}{|c|c|c|c|c|c|}
\hline Sasaran Program & Indik & tor Kinerja Program & Target & Realisasi & Capaian \\
\hline \multirow{6}{*}{$\begin{array}{l}\text { Meningkatnya } \\
\text { relevansi, } \\
\text { kualitas, dan } \\
\text { kuantitas } \\
\text { sumber daya } \\
\text { Iptek dan Dikti }\end{array}$} & 1 & $\begin{array}{l}\text { Persentase dosen } \\
\text { berkualifikasi S3 }\end{array}$ & $18,4 \%$ & $16,82 \%$ & $88 \%$ \\
\hline & 2 & $\begin{array}{l}\text { Jumlah SDM yang } \\
\text { meningkat karirnya }\end{array}$ & 20.364 & 12.262 & $60 \%$ \\
\hline & 3 & $\begin{array}{l}\text { Jumlah SDM yang } \\
\text { meningkat } \\
\text { kompetensinya }\end{array}$ & 2.641 & 1.310 & $50 \%$ \\
\hline & 4 & $\begin{array}{l}\text { Jumlah revitalisasi } \\
\text { sarpras PTN }\end{array}$ & 118 & 118 & $100 \%$ \\
\hline & 5 & $\begin{array}{l}\text { Persentase SDM Litbang } \\
\text { Berkualifikasi S3 }\end{array}$ & $14.6 \%$ & $13.2 \%$ & $90 \%$ \\
\hline & & Rataan Kinerja & & & $77,60 \%$ \\
\hline
\end{tabular}

Sumber: Lakip Ditjen Sumber Daya Iptek dan Dikti 2019

Berdasarkan data peningkatan kompetensi pegawai Tahun 2020, menunjukkan tiga jenis pelatihan yang telah dilaksanakan bagi 121 total pegawai. Pelatihan kepemimpinan diikuti 58 pegawai (48\%), pelatihan peningkatan kompetensi manajerial diikuti 21 pegawai (17\%) dan pelatihan teknis sesuai bidang diikuti 53 pegawai (44\%). Hal ini merupakan salah satu faktor yang ditengarai penyebab kinerja belum maksimal. Oleh sebab itu tujuan penulis melakukan penelitian ini untuk mengetahui gambaran mengenai Faktor Internal Pegawai, Kepemimpinan, Tim Kerja, Sistem Kerja, Lingkungan Kerja dan Kinerja Pegawai di Direktorat Sumber Daya serta Mengetahui Pengaruh Faktor internal pegawai, Kepemimpinan, Tim kerja, Sistem kerja dan Lingkungan Kerja terhadap Kinerja Pegawai di Direktorat Sumber Daya.

\section{TINJAUAN LITERATUR}

Berdasarkan Peraturan Kepala Badan Kepegawaian Negara Nomor 7 Tahun 2013 tentang Pedoman Penyusunan Standar Kompetensi Manajerial Pegawai Negeri Sipil, dalam pendahuluan dinyatakan bahwa untuk mendukung terwujudnya profesionalisme Pegawai Negeri Sipil diperlukan standar kompetensi jabatan yang wajib dimiliki oleh setiap Pegawai Negeri Sipil, yang terdiri dari 
Standar Kompetensi Teknis dan Standar Kompetensi Manajerial. Standar Kompetensi Manajerial merupakan persyaratan kompetensi manajerial minimal yang harus dimiliki oleh seorang Pegawai Negeri Sipil dalam melaksanakan tugas jabatan.

Menurut Armstrong dan Baron (2005) dalam Wibowo (2011), kinerja merupakan hasil pekerjaan yang mempunyai hubungan kuat dengan tujuan strategis organisasi, kepuasan konsumen, dan memberikan kontribusi ekonomi. Faktor-faktor yang mempengaruhi kinerja, antara lain dikemukakan Amstrong dan Baron (2005) dalam Wibowo (2011), yaitu: a) Personal factors, ditunjukkan oleh tingkat keterampilan, kompetensi yang dimiliki, motivasi dan komitmen individu; b) Leadership factors, ditentukan oleh kualitas dorongan, bimbingan, dan dukungan yang dilakukan manajer dan team leader; c) Team factors, ditunjukkan oleh kualitas dukungan yang diberikan oleh rekan sekerja; d) System factors, ditunjukkan oleh adanya sistem kerja dan fasilitas yang diberikan organisasi; e) Contextual/situational factors, ditunjukkan oleh tingginya tingkat tekanan dan perubahan lingkungan internal dan eksternal. Kepemimpinan adalah kemampuan untuk mempengaruhi bawahan dalam mencapai sasaran (Robin, 2006). Sedangkan menurut Yuki (2005), kepemimpinan adalah suatu proses mempengaruhi orang lain untuk memahami dan setuju dengan apa yang perlu dilakukan dan bagaimana tugas itu dapat dilakukan secara efektif, serta proses untuk dapat memberi fasilitas untuk mencapai tujuan bersama.

Menurut Hunsaker (2001), tim kerja adalah kelompok yang memiliki keterampilan yang saling melengkapi dan memiliki komitmen untuk mencapai tujuan bersama dengan efektif dan efisien. Sedangkan Kerjasama tim (teamwork) adalah sekumpulan pegawai yang dibawah koordinasi ketua tim atau seorang manajer (Mangkuprawira, 2009). Sistem kerja adalah suatu sistem yang kompleks mencakup manusia, mesin dan organisasi (Mustafa et al., 2009). Lingkungan kerja dapat diartikan sebagai kekuatan yang mempengaruhi, baik secara langsung maupun tidak langsung terhadap kinerja organisasi atau instansi (Terry, 2016).

Pada Penelitian terdahulu, (Yuliarti \& Anggriani, 2014), menunjukkan bahwa dari lima sistem yang mempengaruhi kinerja pegawai, terdapat empat faktor yaitu personal factors, team factors, system factor, dan contextual factors mendapat persepsi dari responden dengan kriteria setuju. Hal ini berarti keempat faktor tersebut mempengaruhi kinerja pegawai. Sedangkan satu faktor yaitu leadership factors mendapat persepsi sangat setuju, artinya pemimpin sangat mempengaruhi kinerja pegawai.

\section{METODE}

\section{Populasi dan Sampel}

Populasi dalam penelitian ini adalah 121 pegawai, terdiri dari 67 Orang PNS (Pegawai Negeri Sipil) dan 54 Orang PPNPN (Pegawai Pemerintah Non Pegawai Negeri). Ukuran sample minimum adalah 100 sampai dengan 200 untuk teknik analisis SEM (Structural Equation Modelling) (Ferdinand, 2002, Hair et al., 2006). Oleh karena itu, penulis mengambil seluruh populasi, sebanyak 121 sebagai bahan penelitian.

\section{Metode Pengambilan Sampel}

Teknik pengambilan sampel yang dilakukan dalam penelitian ini adalah dengan menggunakan kuesioner dengan pilihan jawaban: 1) Sangat Setuju. 2) Setuju. 3) Ragu-ragu. 4). Tidak Setuju. 5) Sangat Tidak Setuju. Untuk mengetahui faktor-faktor apa saja yang mempengaruhi keputusan pegawai dalam kuesioner digunakan skala linkert, dengan rumus:

$$
R S=\frac{\mathrm{n}(\mathrm{m}-1)}{\mathrm{m}}=\frac{121(5-1)}{5}=96,8=97
$$




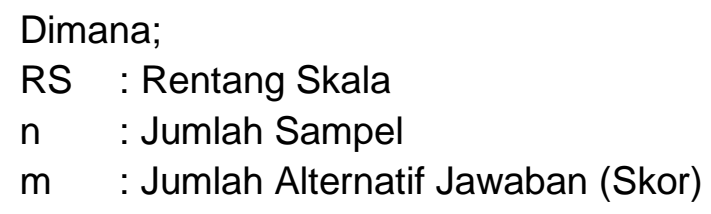

Tabel 2. Rentang Skala

\begin{tabular}{cll}
\hline Skala Skor & Rentang Skala & \multicolumn{1}{c}{ Kriteria } \\
\hline 1 & $121-218$ & Sangat Tidak Setuju (STS) \\
2 & $219-316$ & Tidak Setuju (TS) \\
3 & $317-414$ & Ragu-Ragu (RR) \\
4 & $415-512$ & Setuju (S) \\
5 & $513-605$ & Sangat Setuju (SS) \\
\hline
\end{tabular}

Untuk memudahkan identifikasi posisi persepsi responden, maka dibuat bar skala yang didasarkan pada tabel rentang skala diatas. Lebih lanjut bar skala yang tersusun seperti terlihat pada gambar 1.

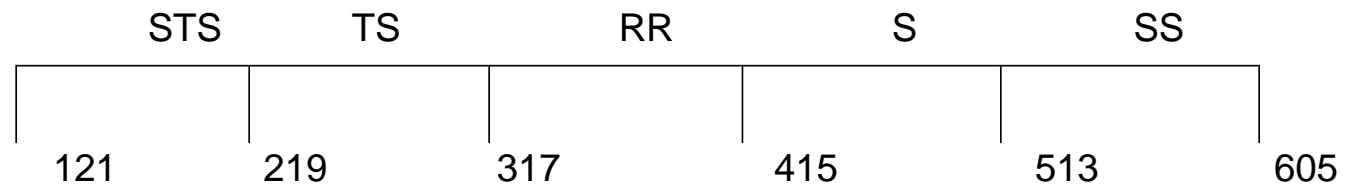

Gambar 1. Bar Skala

Sumber: Diolah, 2020

\section{Alat Analisis}

Pada penelitian ini menggunakan alat bantu statistik dengan analisis Partial Least Squares Structural Equation Modeling (PLS-SEM) dengan aplikasi SmartPLS 3. Karena analisis ini dapat menunjukkan nilai hubungan antar variabel baik itu variabel independen, variabel dependen, dan variabel mediasi (David, 2016). Output dari analisis PLS-SEM berupa path coefficients untuk inner model, direct dan indirect, total path coefficients, outer model measurement loading and weight, dan bootstrapped significance output untuk menguji hipotesis.

\section{Validitas dan Reliabilitas}

Uji Validitas terdiri atas convergent validity, discriminant validity dan Uji Reliabilitas terdiri atas composite reliability dan Cronbach Alpha.

\section{Metode Analisis Data}

Langkah-langkah analisis data yaitu sebagai berikut: 1) Perancangan Outer Model (Model pengukuran). 2) Perancangan Inner Model (Model Struktural). 3) Evaluasi Inner Model. 4) Pengujian Hipotesis.

\section{HASIL DAN PEMBAHASAN}

\section{Analisis Deskriptif: Rentang Skala}

\section{Faktor Internal Pegawai}

Secara kontinum, faktor Internal Pegawai berjumlah 558.75 berada pada range (rentang skala) 513 hingga 605 atau kriteria Sangat Setuju (SS). Informasi responden terkait faktor kepemimpinan selengkapnya disajikan pada Tabel 3. 
Tabel 3. Tanggapan Responden Faktor Internal Pegawai

\begin{tabular}{|c|c|c|c|c|c|c|c|c|}
\hline \multirow[t]{2}{*}{ Kode } & \multirow[t]{2}{*}{ Indikator / kuesioner } & \multicolumn{5}{|c|}{ Tanggapan Pegawai } & \multirow[t]{2}{*}{ Jumlah } & \multirow[t]{2}{*}{ Kriteria } \\
\hline & & SS & $\mathbf{S}$ & $\mathbf{R R}$ & TS & STS & & \\
\hline Fl1 & $\begin{array}{l}\text { Keterampilan pegawai } \\
\text { mendukung mutu kinerja }\end{array}$ & 74 & 46 & 1 & 0 & 0 & 557 & Sangat Setuju \\
\hline $\mathrm{FI} 2$ & $\begin{array}{l}\text { Kompetensi pegawai } \\
\text { mempengaruhi mutu } \\
\text { kinerja }\end{array}$ & 75 & 44 & 2 & 0 & 0 & 557 & Sangat Setuju \\
\hline $\mathrm{FI3}$ & $\begin{array}{l}\text { Motivasi untuk bekerja } \\
\text { lebih baik akan } \\
\text { mempengaruhi kinerja }\end{array}$ & 85 & 34 & 1 & 1 & 0 & 566 & Sangat Setuju \\
\hline $\mathrm{Fl} 4$ & $\begin{array}{l}\text { Komitmen pegawai } \\
\text { terhadap organisasi akan } \\
\text { meningkatkan mutu } \\
\text { kinerja }\end{array}$ & 72 & 48 & 1 & 0 & 0 & 555 & Sangat Setuju \\
\hline \multicolumn{7}{|c|}{ Rata-rata } & 558.75 & Sangat Setuju \\
\hline
\end{tabular}

\section{Faktor Kepemimpinan}

Secara kontinum, faktor kepemimpinan berjumlah 548.75 berada pada range 513 hingga 605 atau kriteria Sangat Setuju (SS). Informasi responden terkait faktor kepemimpinan selengkapnya disajikan pada Tabel 4.

Tabel 4. Tanggapan Responden Faktor Kepemimpinan

\begin{tabular}{|c|c|c|c|c|c|c|c|c|}
\hline \multirow[t]{2}{*}{ Kode } & \multirow[t]{2}{*}{ Indikator / kuesioner } & \multicolumn{5}{|c|}{ Tanggapan Pegawai } & \multirow[t]{3}{*}{ Jumlah } & \multirow[t]{3}{*}{ Kriteria } \\
\hline & & SS & $\mathbf{S}$ & $\mathbf{R R}$ & TS & STS & & \\
\hline \multirow{3}{*}{ KE1 } & $\begin{array}{l}\text { Dorongan dari pimpinan } \\
\text { mempengaruhi }\end{array}$ & & & & & & & \\
\hline & pegawai & 66 & 53 & 2 & 0 & 0 & 548 & Sangat Setuju \\
\hline & $\begin{array}{l}\text { Kinerja pegawai yang baik } \\
\text { dan konsisten, dikarenakan }\end{array}$ & & & & & & & \\
\hline \multirow{2}{*}{ KE2 } & bimbingan dari pimpinan & 65 & 54 & 2 & 0 & 0 & 547 & Sangat Setuju \\
\hline & $\begin{array}{lr}\text { Dukungan } & \text { pimpinan } \\
\text { mempengaruhi } & \text { mutu }\end{array}$ & & & & & & & \\
\hline KE3 & kinerja pegawai & 68 & 51 & 2 & 0 & 0 & 550 & Sangat Setuju \\
\hline KE4 & $\begin{array}{l}\text { Kinerja pegawai dapat } \\
\text { mencapai target jika diberi } \\
\text { petunjuk dan arahan dari } \\
\text { pimpinan }\end{array}$ & 68 & 51 & 2 & 0 & 0 & 550 & Sanart Sotuic \\
\hline \multicolumn{7}{|c|}{ Rata-rata } & 548.75 & Sanqat Setuiu \\
\hline
\end{tabular}

\section{Faktor Tim Kerja}

Secara kontinum, faktor tim kerja berjumlah 527.50 berada pada range 513 hingga 605 atau kriteria Sangat Setuju (SS). Informasi responden terkait faktor tim kerja selengkapnya disajikan pada Tabel 5.

Tabel 5. Tanggapan Responden Faktor Tim Kerja

\begin{tabular}{|c|c|c|c|c|c|c|c|c|c|}
\hline \multirow[t]{2}{*}{ Kode } & \multicolumn{2}{|c|}{ Indikator / kuesioner } & \multicolumn{5}{|c|}{ Tanggapan Pegawai } & \multirow[t]{2}{*}{ Jumlah } & \multirow[t]{2}{*}{ Kriteria } \\
\hline & & & SS & $\mathbf{S}$ & $\mathbf{R R}$ & TS & STS & & \\
\hline TM1 & $\begin{array}{l}\text { Rekan } \\
\text { mempengaruhi } \\
\text { kinerja pegawai. }\end{array}$ & $\begin{array}{r}\text { sekerja } \\
\text { mutu }\end{array}$ & 53 & 61 & 5 & 2 & 0 & 528 & Sangat Setuju \\
\hline
\end{tabular}




\begin{tabular}{|c|c|c|c|c|c|c|c|c|}
\hline TM2 & $\begin{array}{lr}\text { Kerja sama } & \text { dan } \\
\text { hubungan baik dengan } \\
\text { rekan sekerja akan } \\
\text { mempengaruhi } \\
\text { kinerja pegawai. }\end{array}$ & 65 & 54 & 2 & 0 & 0 & 547 & Sangat Setuju \\
\hline TM3 & $\begin{array}{l}\text { Adanya dukungan rekan } \\
\text { sekerja, meningkatkan } \\
\text { mutu kinerja. }\end{array}$ & 45 & 71 & 4 & 1 & 0 & 523 & Sangat Setuju \\
\hline TM4 & $\begin{array}{l}\text { Saran / petunjuk dari } \\
\text { rekan sekerja mengenai } \\
\text { pelaksanaan tugas akan } \\
\text { meningkatkan mutu } \\
\text { kinerja. }\end{array}$ & 39 & 71 & 11 & 0 & 0 & 512 & Sangat Setuju \\
\hline
\end{tabular}

\section{Faktor Sistem Kerja}

Secara kontinum, faktor sistem kerja berjumlah 556.25 berada pada range 513 hingga 605 atau kriteria Sangat Setuju (SS). Informasi responden terkait faktor sistem kerja selengkapnya disajikan pada Tabel 6.

Tabel 6. Tanggapan Responden Faktor Sistem Kerja

\begin{tabular}{|c|c|c|c|c|c|c|c|c|}
\hline \multirow[t]{2}{*}{ Kode } & \multirow[t]{2}{*}{ Indikator / kuesioner } & \multicolumn{5}{|c|}{ Tanggapan Pegawai } & \multirow[t]{2}{*}{ Jumlah } & \multirow[t]{2}{*}{ Kriteria } \\
\hline & & SS & $\mathbf{S}$ & $\mathbf{R R}$ & TS & STS & & \\
\hline SI1 & $\begin{array}{l}\text { Sistem yang berjalan } \\
\text { didalam organisasi } \\
\text { mempengaruhi mutu } \\
\text { kinerja pegawai. }\end{array}$ & 78 & 40 & 3 & 0 & 0 & 559 & Sangat Setuju \\
\hline SI2 & $\begin{array}{lr}\text { Fasilitas } & \text { yang } \\
\text { disediakan } & \text { dalam } \\
\text { bekerja } & \\
\text { mempengaruhi } & \text { mutu } \\
\text { kinerja pegawai. } & \end{array}$ & 78 & 40 & 3 & 0 & 0 & 559 & Sangat Setuju \\
\hline SI3 & $\begin{array}{lr}\text { Sistem } & \text { perencanaan } \\
\text { jenjang } & \text { karier } \\
\text { memberi } & \text { motivasi } \\
\text { untuk meningkatkan } \\
\text { mutu kerja pegawai. }\end{array}$ & 65 & 52 & 4 & 0 & 0 & 545 & Sangat Setuju \\
\hline SI4 & $\begin{array}{l}\text { Dukungan teknologi } \\
\text { informasi mendukung } \\
\text { pelaksanaan tugas } \\
\text { dan fungsi lebih cepat } \\
\text { dan tepat. }\end{array}$ & 81 & 37 & 3 & 0 & 0 & 562 & Sangat Setuju \\
\hline & & ata & & & & & 556,25 & Sangat Setuju \\
\hline
\end{tabular}

\section{Faktor Lingkungan Kerja}

Secara kontinum, faktor lingkungan kerja berjumlah 474.75 berada pada range 415 hingga 512 atau kriteria Setuju (S). Informasi responden terkait faktor lingkungan kerja selengkapnya disajikan pada Tabel 7. 
Tabel 7. Tanggapan Responden Faktor Lingkungan Kerja

\begin{tabular}{|c|c|c|c|c|c|c|c|c|}
\hline \multirow[t]{2}{*}{ Kode } & \multirow[t]{2}{*}{ Indikator / kuesioner } & \multicolumn{5}{|c|}{ Tanggapan Pegawai } & \multirow[t]{2}{*}{ Jumlah } & \multirow[t]{2}{*}{ Kriteria } \\
\hline & & SS & $\mathbf{S}$ & $\mathbf{R R}$ & TS & STS & & \\
\hline LK1 & $\begin{array}{l}\text { Tekanan dari, pimpinan / } \\
\text { tenggat waktu kerja, } \\
\text { dalam pelaksanaan tugas } \\
\text { mempengaruhi psikologis } \\
\text { pegawai sehingga mutu } \\
\text { kinerja menjadi lebih } \\
\text { rendah. }\end{array}$ & 27 & 73 & 20 & 1 & 0 & 489 & Setuju \\
\hline LK2 & $\begin{array}{l}\text { Ketidaknyamanan } \\
\text { suasana organisasi } \\
\text { mempengaruhi mutu } \\
\text { kinerja menjadi lebih } \\
\text { rendah. }\end{array}$ & 18 & 69 & 31 & 3 & 0 & 465 & Setuju \\
\hline LK3 & $\begin{array}{lr}\text { Dukungan } & \text { dari } \\
\text { lingkungan terdekat } \\
\text { dengan instansi akan } \\
\text { mempengaruhi } & \text { mutu } \\
\text { kinerja pegawai } & \end{array}$ & 24 & 76 & 20 & 1 & 0 & 486 & Setuju \\
\hline LK4 & $\begin{array}{lr}\text { Kinerja } & \text { pegawai } \\
\text { dipengaruhi } & \text { perubahan } \\
\text { organisasi } & \end{array}$ & 15 & 69 & 34 & 3 & 0 & 459 & Setuju \\
\hline
\end{tabular}

\section{Analisis Verifikatif}

\section{Pengukuran Validitas}

1. Convergent Validity - Loading Factor / Outer Loadings

Untuk pengukuran validitas indikator dapat dilihat dari output SmartPLS yaitu outer loadings. Indikator dinyatakan valid apabila mempunyai nilai outer loadings di atas 0,5 (nilai outer loadings > 0,5) (Imam, 2014).

Tabel 8. Ouput Nilai Outer Loadings

\begin{tabular}{ccccc}
\hline Variabel & Indikator & Nilai Outer Loadings & Nilai Kritis & Keterangan \\
\hline \multirow{2}{*}{ Faktor Internal } & FI1 & 0,837 & 0,5 & Valid \\
(FI) & FI2 & 0,843 & 0,5 & Valid \\
& FI3 & 0,731 & 0,5 & Valid \\
Kepemimpinan & FI4 & 0,790 & 0,5 & Valid \\
(KE) & KE2 & 0,971 & 0,5 & Valid \\
& KE3 & 0,971 & 0,5 & Valid \\
& KE4 & 0,962 & 0,5 & Valid \\
Tim Kerja (TM) & TM1 & 0,970 & 0,5 & Valid \\
& TM2 & 0,922 & 0,5 & Valid \\
& TM3 & 0,923 & 0,5 & Valid \\
Sistem Kerja (SI) & TM4 & 0,716 & 0,5 & Valid \\
& SI1 & 0,733 & 0,5 & Valid \\
& SI2 & 0,967 & 0,5 & Valid \\
& SI3 & 0,945 & 0,5 & Valid \\
Lingkungan Kerja & SI4 & 0,712 & 0,5 & Valid \\
(LK) & LK1 & 0,971 & 0,5 & Valid \\
& LK2 & 0,916 & 0,5 & Valid \\
Kinerja Pegawai & LK3 & 0,826 & 0,5 & Valid \\
(KP) & KK4 & 0,923 & 0,5 & Valid \\
& KP1 & 0,798 & 0,5 & Valid \\
& & 0,772 & 0,5 & Valid \\
& & 0,779 & 0,5 & Valid \\
\hline
\end{tabular}




\begin{tabular}{cccc}
\hline KP11 & 0,744 & 0,5 & Valid \\
KP12 & 0,779 & 0,5 & Valid \\
KP2 & 0,810 & 0,5 & Valid \\
KP3 & 0,784 & 0,5 & Valid \\
KP4 & 0,762 & 0,5 & Valid \\
KP5 & 0,847 & 0,5 & Valid \\
KP6 & 0,718 & 0,5 & Valid \\
KP7 & 0,840 & 0,5 & Valid \\
KP8 & 0,878 & 0,5 & Valid \\
KP9 & 0,868 & 0,5 & Valid \\
\hline
\end{tabular}

2. Convergent Validity - Average Variance Extracted (AVE). Selain melihat nilai outer loadings, evaluasi outer model terhadap validitas juga dapat dilihat dari ouput Average Variance Extracted (AVE) pada SmartPLS. Suatu indikator dinyatakan valid jika memiliki nilai AVE di atas 0,5 (Imam, 2014). Nilai AVE pada evaluasi outer model dengan menggunakan SmartPLS.

Tabel 9. Nilai Average Variance Extracted (AVE)

\begin{tabular}{lc}
\hline \multicolumn{1}{c}{ Variabel } & Average Variance Extracted(AVE) \\
\hline Faktor Internal (FI) & 0,642 \\
Kepemimpinan (KE) & 0,938 \\
Tim Kerja (TM) & 0,688 \\
Sistem Kerja (SI) & 0,820 \\
Lingkungan Kerja (LK) & 0,752 \\
Kinerja Pegawai (KP) & 0,640 \\
\hline
\end{tabular}

3. Discriminant Validity - Cross Loading. Selanjutnya, indikator dengan model reflektif juga perlu dilakukan uji discriminant validity dengan melihat dari nilai cross loading (David, 2016; Sarstedt et al., 2017; Vincenzo et al., 2010). Suatu indikator dapat dinyatakan valid apabila mempunyai nilai cross loadings yang lebih tinggi terhadap variabelnya dibandingkan terhadap variabel lain (Imam, 2014).

Tabel 10. Output Nilai Cross Loadings

\begin{tabular}{ccccccc}
\hline Indikator & $\begin{array}{c}\text { Faktor } \\
\text { Internal (FI) }\end{array}$ & $\begin{array}{c}\text { Kepemimpinan } \\
\text { (KE) }\end{array}$ & $\begin{array}{c}\text { Kinerja } \\
\text { Pegawai (KP) }\end{array}$ & $\begin{array}{c}\text { Lingkungan } \\
\text { Kerja (LK) }\end{array}$ & $\begin{array}{c}\text { Sistem } \\
\text { Kerja (SI) }\end{array}$ & $\begin{array}{c}\text { Tim Kerja } \\
\text { (TM) }\end{array}$ \\
\hline FI1 & $\mathbf{0 , 8 3 7}$ & 0,434 & 0,264 & 0,133 & 0,225 & 0,242 \\
FI2 & $\mathbf{0 , 8 4 3}$ & 0,394 & 0,293 & 0,172 & 0,313 & 0,260 \\
FI3 & $\mathbf{0 , 7 3 1}$ & 0,487 & 0,234 & 0,080 & 0,296 & 0,306 \\
FI4 & $\mathbf{0 , 7 9 0}$ & 0,356 & 0,218 & 0,112 & 0,207 & 0,205 \\
KE1 & 0,510 & $\mathbf{0 , 9 7 1}$ & 0,267 & 0,159 & 0,200 & 0,329 \\
KE2 & 0,506 & $\mathbf{0 , 9 7 1}$ & 0,256 & 0,134 & 0,180 & 0,309 \\
KE3 & 0,494 & $\mathbf{0 , 9 6 2}$ & 0,257 & 0,155 & 0,188 & 0,331 \\
KE4 & 0,505 & $\mathbf{0 , 9 7 0}$ & 0,252 & 0,175 & 0,203 & 0,321 \\
TM1 & 0,289 & 0,307 & 0,292 & 0,198 & 0,241 & $\mathbf{0 , 9 2 2}$ \\
TM2 & 0,287 & 0,307 & 0,291 & 0,198 & 0,241 & $\mathbf{0 , 9 2 3}$ \\
TM3 & 0,205 & 0,198 & 0,167 & 0,235 & 0,219 & $\mathbf{0 , 7 1 6}$ \\
TM4 & 0,253 & 0,271 & 0,254 & 0,351 & 0,233 & $\mathbf{0 , 7 3 3}$ \\
SI1 & 0,292 & 0,197 & 0,359 & 0,163 & $\mathbf{0 , 9 6 7}$ & 0,272 \\
SI2 & 0,287 & 0,185 & 0,358 & 0,118 & $\mathbf{0 , 9 4 5}$ & 0,212 \\
SI3 & 0,331 & 0,157 & 0,263 & 0,219 & $\mathbf{0 , 7 1 2}$ & 0,320 \\
SI4 & 0,294 & 0,181 & 0,382 & 0,189 & $\mathbf{0 , 9 7 1}$ & 0,238 \\
LK1 & 0,118 & 0,126 & 0,332 & $\mathbf{0 , 9 1 6}$ & 0,149 & 0,223 \\
LK2 & 0,175 & 0,156 & 0,230 & $\mathbf{0 , 8 2 6}$ & 0,182 & 0,233 \\
LK3 & 0,128 & 0,136 & 0,338 & $\mathbf{0 , 9 2 3}$ & 0,159 & 0,321 \\
LK4 & 0,152 & 0,155 & 0,210 & $\mathbf{0 , 7 9 8}$ & 0,167 & 0,213 \\
KP1 & 0,227 & 0,221 & $\mathbf{0 , 7 7 2}$ & 0,149 & 0,295 & 0,270 \\
KP2 & 0,254 & 0,215 & $\mathbf{0 , 8 1 0}$ & 0,226 & 0,314 & 0,211 \\
KP3 & 0,212 & 0,212 & $\mathbf{0 , 7 8 4}$ & 0,366 & 0,295 & 0,237 \\
\hline
\end{tabular}




\begin{tabular}{lllllll}
\hline KP4 & 0,216 & 0,208 & $\mathbf{0 , 7 6 2}$ & 0,148 & 0,286 & 0,309 \\
KP5 & 0,214 & 0,184 & $\mathbf{0 , 8 4 7}$ & 0,251 & 0,346 & 0,136 \\
KP6 & 0,205 & 0,180 & $\mathbf{0 , 7 1 8}$ & 0,406 & 0,357 & 0,237 \\
KP7 & 0,215 & 0,210 & $\mathbf{0 , 8 4 0}$ & 0,289 & 0,321 & 0,162 \\
KP8 & 0,244 & 0,207 & $\mathbf{0 , 8 7 8}$ & 0,316 & 0,328 & 0,202 \\
KP9 & 0,223 & 0,200 & $\mathbf{0 , 8 6 8}$ & 0,284 & 0,306 & 0,135 \\
KP10 & 0,347 & 0,221 & $\mathbf{0 , 7 7 9}$ & 0,208 & 0,249 & 0,433 \\
KP11 & 0,329 & 0,269 & $\mathbf{0 , 7 4 4}$ & 0,212 & 0,266 & 0,282 \\
KP12 & 0,350 & 0,228 & $\mathbf{0 , 7 7 9}$ & 0,244 & 0,263 & 0,351 \\
\hline
\end{tabular}

\section{Pengukuran Reliability}

1. Composite Reliability. Nilai composite reliability dari blok indikator yang mengukur variabel dapat dijadikan aturan sebagai indikator tersebut reliabel atau tidak. Untuk dapat dikatakan suatu indikator tersebut reliabel, maka nilai composite reliability harus di atas 0,7 (Imam, 2014).

Tabel 11. Output Composite Reliability

\begin{tabular}{lc}
\hline \multicolumn{1}{c}{ Variabel } & Composite Reliability \\
\hline Faktor Internal (FI) & 0,877 \\
Kepemimpinan (KE) & 0,984 \\
Tim Kerja (TM) & 0,897 \\
Sistem Kerja (SI) & 0,947 \\
Lingkungan Kerja (LK) & 0,924 \\
Kinerja Pegawai (KP) & 0,955 \\
\hline
\end{tabular}

2. Cronbachs alpha. Pengukuran reliabilitas juga dapat dilihat dengan nilai cronbachs alpha dari hasil output SmartPLS. Suatu variabel dikatakan reliabel jika memiliki nilai cronbachs alpha di atas 0,6 (Imam, 2014).

Tabel 12. Output Cronbachs alpha

\begin{tabular}{lc}
\hline \multicolumn{1}{c}{ Variabel } & Cronbachs alpha \\
\hline Faktor Internal (FI) & 0,814 \\
Kepemimpinan (KE) & 0,978 \\
Tim Kerja (TM) & 0,847 \\
Sistem Kerja (SI) & 0,922 \\
Lingkungan Kerja (LK) & 0,894 \\
Kinerja Pegawai (KP) & 0,948 \\
\hline
\end{tabular}

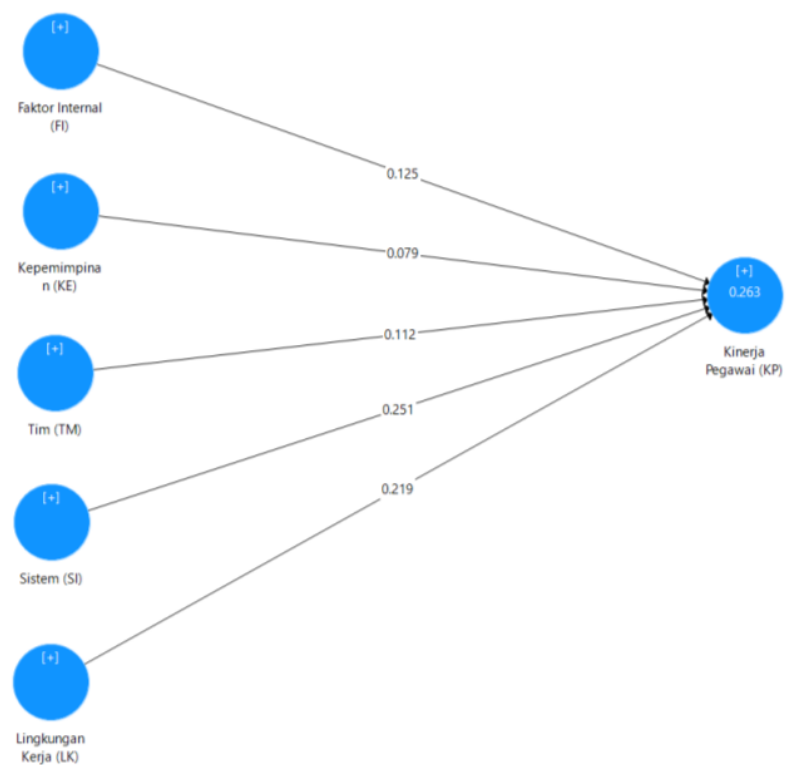

Gambar 2. Inner Model 
Inner model dievaluasi dengan menggunakan nilai $R$-square, sebagai koefisien determinasi pada variabel endogen (David, 2016). Variabel endogen adalah variabel yang diprediksi oleh satu atau lebih variabel yang lain (Imam, 2014). Inner model yang memiliki hasil $R$-square lebih dari 0,67 mengindikasikan bahwa model tersebut "baik". Jika memiliki hasil $R$-square lebih dari 0,33 maka model tersebut "moderat". Jika memiliki hasil $R$-square kurang dari 0,33 maka model tersebut dikatakan "lemah" (Imam, 2014).

Path Coefficients adalah nilai untuk menunjukkan arah hubungan variable. Apakah Hipotesa 1, Hipotesa 2, Hipotesa 3, Hipotesa 4 dan Hipotesa 5 memiliki arah Positif atau Negatif. Arah Positif jika nilai antara direntang 0 (nol) sampai dengan 1 (satu). Sedangkan arah negatif jika nilai antara direntang 0 (nol) sampai dengan -1 (minus satu).

Tabel 13. Path Coefficients

\begin{tabular}{lc}
\hline \multicolumn{1}{c}{ Hubungan Variabel } & Path Coefficients \\
\hline Faktor Internal Pegawai (FI) -> Kinerja Pegawai (KP) & 0,125 \\
Kepemimpinan (KE) -> Kinerja Pegawai (KP) & 0,079 \\
Tim Kerja (TM) -> Kinerja Pegawai (KP) & 0,112 \\
Sistem Kerja (SI) -> Kinerja Pegawai (KP) & 0,251 \\
Lingkungan Kerja (LK) -> Kinerja Pegawai (KP) & 0,219 \\
\hline
\end{tabular}

Pengujian hipotesis dilakukan dengan metode bootstrapping pada SmartPLS, untuk melihat ukuran signifikan dari hipotesis dapat digunakan dengan uji $\mathrm{T}$, dengan melihat nilai $\mathrm{P}$ value yang diukur dengan perbandingan terhadap taraf kesalahan atau lebih dikenal dengan taraf signifikansi. Pada penelitian ini taraf signifikansi yang ditentukan peneliti adalah $10 \%$ atau 0,1 . Dengan demikian, apabila nilai $P$ value antara hubungan variabel tersebut kurang dari sama dengan 0,1 ( $P$ value hitung $\leq 0,1$ ) maka dinyatakan hipotesis diterima (David, 2016; Sudaryono, 2017).

Tabel 14. Pengujian Hipotesis

\begin{tabular}{llccc}
\hline & \multicolumn{1}{c}{ Hipotesis } & P Kritis & Output P Value & Keterangan \\
\hline Ha1 & Faktor Internal (FI) -> Kinerja Pegawai (KP) & 0,1 & 0,000 & Hipotesis diterima \\
Ha2 & Kepemimpinan (KE) -> Kinerja Pegawai (KP) & 0,1 & 0,000 & Hipotesis diterima \\
Ha3 & Tim Kerja (TM) -> Kinerja Pegawai (KP) & 0,1 & 0,000 & Hipotesis diterima \\
Ha4 & Sistem Kerja (SI) -> Kinerja Pegawai (KP) & 0,1 & 0,000 & Hipotesis diterima \\
Ha5 & Lingkungan Kerja (LK) -> Kinerja Pegawai (KP) & 0,1 & 0,000 & Hipotesis diterima \\
\hline
\end{tabular}

\section{KESIMPULAN}

Gambaran mengenai Faktor Internal Pegawai, Kepemimpinan, Tim Kerja, Sistem Kerja, Lingkungan Kerja dan Kinerja Pegawai di Direktorat Sumber Daya, berdasarkan hasil rating scale, faktor internal pegawai adalah faktor yang paling dominan mempengaruhi kinerja pegawai. Kemudian diikuti faktor Sistem Kerja, faktor kepemimpinan, faktor Tim Kerja dan terakhir faktor Lingkungan Kerja.

Adapun Kinerja Pegawai di Direktorat Sumber Daya dipengaruhi oleh: 1) Faktor internal pegawai, seperti tingkat keterampilan, kompetensi yang dimiliki, motivasi pegawai, komitmen pegawai itu sendiri. 2) faktor kepemimpinan, yang mempengaruhi para pegawai untuk memahami dan setuju dengan apa yang perlu dilakukan dan bagaimana tugas itu dilakukan secara efektif. 3) faktor tim kerja, yang ditunjukkan oleh kualitas dukungan yang diberikan oleh rekan kerja, seperti hubungan yang baik dengan rekan kerja. 4) faktor sistem kerja, yaitu sistem organisasi dalam pelaksanaan pekerjaan, seperti Sistem Perencanaan Karir, dan fasilitas yang diberikan organisasi yaitu fasilitas yang mempermudah pelaksanaan pekerjaan sesuai tugas dan fungsi seperti 
penerapan Teknologi Informasi. 5) faktor lingkungan kerja seperti tingkat tekanan dan perubahan lingkungan internal dan eksternal dari suatu organisasi.

Implikasi Manajerial penelitian ini bagi Direktorat Sumber Daya, yaitu sebagai input dan saran yang dapat digunakan oleh pimpinan dan juga seluruh pegawai dalam meningkatkan Kinerja Pegawai serta menguatkan Institusi Pemerintah.

\section{DAFTAR PUSTAKA}

Ditjen Sumber Daya Iptek dan Dikti (2019). Laporan Akuntabilitas Kinerja Instansi Pemerintahan (Lakip). Jakarta.

Ferdinand. (2002). Metode Penelitian Manajemen: Pedoman penelitian untuk Skripsi, Tesis, dan Desertasi IImu Manajemen. Semarang: Badan Penerbit Universitas Diponegoro

David, G. (2016). Partial Least Squares: Regression \& Structural Equation Models. North Country: Statistical Publishing Associates

Hunsaker, C. (2001). Management and Organizational. PT Gramedia Pustaka, Jakarta

Imam, G. (2014). Structural Equation Modeling Metode Alternatif dengan Partial Least Squares (PLS). Semarang. Badan Penerbit Universitas Diponegoro.

Mangkuprawira, S. (2009). Horison Bisnis, Manajemen, dan Sumber Daya Manusia. Bogor. ITB Press.

Sarstedt, M., Ringle, C. M., \& Hair, J. F. (2017). Partial least squares structural equation modeling. Handbook of market research, 26(1), 1-40.

Mustafa, S. A., Kamaruddin, S., Othman, Z., \& Mokhtar, M. (2009). Ergonomics Awareness andidentifying Frequently Used Ergonomics programs in Manufacturing Industries Using Quality Function Deployment. American Journal of Scientific Research. 3.51-66.

Perka BKN. Peraturan Kepala Badan Kepegawaian Negara Nomor 7 tentang Pedoman Penyusunan Standar Kompetensi Manajerial Pegawai Negeri Sipil. (2013).

Robbins., \& Stephen P. (2006). Perilaku Organisasi, Edisi kesepuluh. Jakarta: PT Indeks

Sudaryono. (2017). Metodologi Penelitian (1st ed.). Depok: Raja Grafindo Persada.

Terry, R. G. (2016). Prinsip-prinsip Manajemen. Jakarta. PT Bumi Aksara.

Vincenzo, E. V., Wynne, W. C., Jörg, H., \& Huiwen, W. (2010). Handbook of Partial Least Squares: Concepts, Methods and Applications. Switzerland: Springer.

Wibowo. (2011). Manajemen Kinerja. Jakarta: PT. Raja Grafindo Persada.

Yukl, G. (2005). Kepemimpinan Dalam Organisasi, Edisi kelima. Jakarta: PT Indeks.

Yuliarti, D. L., \& Anggriani, I. (2015). Analisis Faktor-Faktor yang Mempengaruhi Kinerja Pegawai Pada Dinas Pendapatan, Pengelolaan Keuangan dan Aset (DPPKA) Kota Bengkulu. Ekombis Review: Jurnal IImiah Ekonomi Dan Bisnis. 2(1). 122-138. 